\title{
Feminismo de mercado: um mapeamento do debate entre feminismos e consumo*
}

\author{
Soraya Barreto Januário**
}

\begin{abstract}
Resumo
O presente artigo parte do debate sobre a mercantilização das bandeiras feministas pela publicidade. Tendo em vista o acirramento do uso dos discursos dos feminismos pelo mercado nos últimos anos, a pesquisa busca explorar e mapear as reflexões sobre representatividade das mulheres na mídia, empoderamento feminino e sobre o processo de comoditização dos feminismos. Com efeito, reflito em torno dos debates acadêmicos que intersectam as áreas de saber dos estudos do consumo e dos feminismos, bem como dos discursos e das práticas publicitárias. Para tal, dialogo criticamente com a noção de "feminismo de mercado", apontando, à luz da pesquisa bibliográfica, potencialidades e lacunas. Por fim, apresento algumas sugestões de possíveis práticas e reflexões que podem auxiliar na análise crítica em torno da mercantilização do discurso feminista.
\end{abstract}

Palavras-chave: Feminismo de mercado, Publicidade, Consumo, Feminismos.

\footnotetext{
* Recebido em 28 de novembro de 2019, aceito em 24 de agosto de 2020.

** Professora e pesquisadora do Departamento de Comunicação e do Programa de Pós-graduação em Direitos Humanos, Universidade Federal de Pernambuco (UFPE), Recife, PE, Brasil. soraya.barreto@ufpe.br / https://orcid.org/0000-00020405-6381
} 
Commodity Feminism: A Mapping of the Debate between Feminisms and Consumption

\section{Abstract}

This article examines the commoditization of feminist themes in advertising. Considering the increased use of feminist discourses by the market in recent years, the study explores and maps reflections on the representativeness of women in the media, female empowerment and the commoditization of feminisms. We reflect on academic debates that intersect the fields of knowledge in consumer studies and feminisms, as well as advertising discourses and practices. To do so, we conduct a critical dialogue with the notion of "commodity feminism", using bibliographic research to identifyits potential and gaps. Finally, we present suggestions for possible practices and reflections that can assist critical analyses about the commodification of feminist discourse.

Keywords: Commodity Feminism, Advertising, Consumption, Feminisms. 


\section{Introdução}

Questões relativas à mulher na publicidade, embora recorrentemente presentes no debate acadêmico (Beleli, 2007), estão longe de serem esgotadas. Apesar de estudos abordarem, sob os mais diversos olhares, algumas perspectivas sobre a mulher, sobre suas representações na mídia $e$ sobre o processo de construção de sua imagem objetificada e hipersexualizada, ainda assim, pude encontrar lacunas epistemológicas nesse objeto de estudo tão rico e difundido, hoje, nas mais diversas áreas de conhecimento. Uma das abordagens possíveis para esse tema é a sua perspectiva pelas lentes da chamada cultura do consumo. Muito embora já realizadas em alguns âmbitos (Moreno, 2008), as consequências desse processo nas relações da sociedade contemporânea são fluidas e multifacetadas. Especialmente, quando imersas num debate tão atual no conglomerado midiático a respeito das bandeiras dos feminismos em "peças publicitárias que sugerem uma 'Primavera Feminista',que estaria elevando as mulheres, mais uma vez, ao status de sujeito político" (Barreto Januário; Veloso, 2017:175) e agente de consumo.

Canclini (1999) defende que, quando escolhemos bens de consumo e nos apropriamos deles, acabamos por definir o que consideramos importante e valioso publicamente para os demais atores sociais. Esses processos e comportamentos são uma das formas genuínas de nos integrarmos e, ao mesmo tempo, de nos distinguirmos em sociedade. É pertinente lembrar que a cidadania não se centra apenas nos direitos reconhecidos pelos aparelhos estatais. Antes, é também associada às práticas sociais e culturais que dão sentido de pertencimento e distinção social (Bourdieu, 2007).

A publicidade acompanha as mudanças em diversos âmbitos sociais. Faz-se flagrante que o debate sobre pautas feministas vem ganhando visibilidade, especialmente nos produtos e discursos voltados para mulheres. O processo de (des)construção de gênero está em constante mudança, e os conceitos de masculinidade e feminilidade vêm sendo ressignificados (Barreto Januário, 2016), rompendo-se com as visões e comportamentos hegemônicos. Com o aumento do poder de compra e do consumo das mulheres, a publicidade "descobriu" esse mercado e teve que moldar novas formas e perspectivas para se comunicar e vender para o público feminino diferenciado. Como efeito, a nova tendência do mercado visa corresponder às novas exigências por parte das consumidoras.

Os anos de 2015 e 2016 foram considerados os períodos do "empoderamento feminino" na publicidade (Barreto Januário; Veloso, 2017), cuja crescente utilização (Lima, 2016) levanta questões acerca da legitimidade e das preocupações éticas das marcas no que toca à igualdade de gênero, pano de fundo das premissas que defendem em suas campanhas.

$\mathrm{O}$ termo que vem sendo corriqueiramente utilizado para definir esse novo fazer na encenação publicitária é o femvertising. A palavra resulta do cruzamento vocabular entre "feminino"- ou feminismo - e "propaganda", em inglês. A expressão passou a ser difundida por Samantha Skey (2015), chefe de vendas da SheKnows (plataforma de mídia para mulheres), após análise no Adweek $^{1}$, em 2014. Os apontamentos finais do painel indicaram que as empresas estão dirigindo seus esforços e investimentos a abordagens diferenciadas como forma de se aproximar do público feminino, buscando a identificação desse nicho com as peças criadas. De acordo com a SheKnows Media, essa estratégia se baseia na ideia de que a publicidade pode capacitar as mulheres, na mesma medida em que vende produtos.

O femvertising é uma tendência crescente do marketing e vem sendo utilizada por grandes marcas como Avon, Dove, Always, Pantene, dentre outras, que usam pautas feministas em suas estratégias publicitárias. Por outro lado, no âmbito dos estudos de gênero, existem correntes que debatem essa nova narrativa de forma cética (McRobbie, 2004; 2009) e que interpretam essas tentativas abarcadas pela transformação do feminismo em mercadoria (Goldman, 1992), tema que vamos debater ao longo do artigo.

No cerne da militância feminista, a preocupação que tais processos deflagram refere-se ao manejo esvaziado das pautas do movimento visando apenas o retorno financeiro. Sugere-se que esse uso do feminismo possa prejudicar o movimento e que o empoderamento feminino

\footnotetext{
1 A Adweek é uma publicação semanal sobre comércio, negócio e publicidade dos Estados Unidos da América que organizou um painel de discussão dedicado ao tema do femvertising. Samantha Skey foi moderadora nesse painel.
} 
transmitido é sem sentido e vazio. Todavia, pretendo estabelecer tensionamentos a respeito dos resultados desses discursos em longo prazo, considerando que a publicidade poderia, também, contribuir no âmago desse debate. Visando, assim, também refletir sobre o uso dos discursos feministas pela publicidade abarcada pela revisão bibliográfica do termo cunhado por Goldman (1992), "fetichismo de mercado", cuja lógica será debatida e aprofundada mais adiante.

Importa dizer que não pretendo me ater, neste artigo, à análise de representações publicitárias específicas com um corpus delimitado. O nosso intuito é promover um mapeamento do tema que dialogue com as bandeiras e pautas feministas, bem como com as estratégias publicitárias e de consumo no debate acadêmico.

Com efeito, é possível afirmar que existem correntes discutindo o encontro entre os feminismos e o consumo de forma mais descrente (McRobbie, 2004; 2009) e que interpretam essas tentativas de defesa das práticas entre as relações de consumo associadas aos feminismos, a partir de um olhar imbricado no feminismo de mercado (Goldman, 1992) e do "ativismo comoditizado" (Mukherjee; Banet-Weiser, 2012). Sobre esse tipo de ativismo as autoras defendem que:

como é característico na forma de mercadoria - produzida por meio do trabalho para fins de comércio e lucro dentro dos mercados e fetichizado na cultura - o ativismo de mercadoria, como o encontramos hoje, oferece percepções críticas na promessa e nos perigos dos modos de resistência baseados no consumidor. Â medida que tomam forma dentro da dinâmica do poder neoliberal (Mukherjee; Banet-Weiser, 2012:2, tradução nossa).

As preocupações em torno do ativismo enquanto um commodity se assemelham ao debate sobre o feminismo e o capitalismo, isto é, consideram o uso de um discurso esvaziado das pautas políticas e valores caros aos feminismos, visando apenas o lucro para as corporações. Para Wendy Brown (2019), a racionalidade neoliberal tem êxito em fazer desaparecerem os poderes sociais e as reivindicações críticas, com a consequente despolitização da vida pública. Pretendo, dessa forma, debater sobre essa pretensa incoerência entre o uso dos feminismos por estruturas que movimentam o capitalismo e que, inicialmente, vão de encontro aos ideais e motivações que estão no âmago do movimento feminista. Assim, busca-se mapear, neste artigo, reflexões sobre o uso dos discursos e das pautas feministas pela cultura do consumo.

\section{Femvertising e Feminismo de mercado: encontros e desencontros}

É possível afirmar que o fenômeno da femvertising está associado a uma lógica mercantilista, que visa atender ou incitar o consumo de bens associados a ideais, potencialmente, dos feminismos. Nota-se o caráter propulsor da cultura de consumo por meio de discursos contemporâneos que seguem a tendência legitimada pela sociedade. Ao entender por cultura de consumo, a assumindo enquanto escopo, as relações dinâmicas que decorrem entre as ações dos consumidores, o mercado e os significados culturais de cada sociedade (Arnould; Thompson, 2005). É possível perceber que a cultura de consumo está no cerne dessas relações sociais em que a cultura, os recursos sociais e materiais, bem como estilos de vida e práticas simbólicas são mediados pelo mercado, os consumidores são tomados como agentes ativos de um sistema que interliga produtos a simbologias. Slater (2002) afirma que a cultura do consumo surge em meados do século XVIII e é concebida como uma expressão de diferenciação social, tida como uma cultura progressista e que atendia aos ideais de modernidade.

Os processos associados à cultura de consumo na contemporaneidade dialogam com esse debate e se somam às reflexões de Lipovetsky e Serroy (2015), que defendem vivermos um "capitalismo artista" numa "era transestética". A proposta apresentada pelos autores argumenta que estamos inseridos numa estrutura e numa cultura de consumo que apela à estética, ao belo, às emoções e aos valores sociais, a fim de nos levar a consumir mais. Seja por nos identificarmos com o produto, com ideais, causas ou valores. Lipovetsky e Serroy (2015) argumentam que, quanto mais esses signos estéticos estejam presentes em diversas esferas da vida cotidiana, mais a realidade do mundo pode ser fragmentada e compartimentada. Isso institui uma busca pela satisfação via consumo desenfreado, efêmero e superficial, valores que parecem estar perpassando também o 
debate em torno dos feminismos, produzindo-se a ideia de um feminismo empacotado e pronto para consumo através de produtos das mais diferentes esferas.

Seria possivel sugerir a emergência de um novo cenário social em torno dos feminismos? As impressões expostas no presente texto dialogam com o nosso campo de saber, a comunicação publicitária e a militância. Tal interlocução gera conflitos que conversam com as visões defendidas pelos pós-feminismos, propostas por Rosalind Gill (2007), que debateremos à frente.

É inegável que as pautas e valores dos feminismos têm chegado a mais mulheres e têm feito parte de um agendamento midiático constante. Se, por um lado, percebo a lógica perversa por trás do sistema neoliberal, que esvazia debates políticos de importância, como é o caso das pautas feministas, transformando-as em mercadoria associada ao capitalismo transestético (Lipovestky e Serroy, 2015). Por outro lado, não posso deixar de vislumbrar a compreensão de que a mídia possui um caráter pedagógico (Louro, 2008) e funciona também como um dispositivo que "tem significado dar conta, de alguma forma, dessas relações entre cultura, sujeito e sociedade" (Fisher, 2002:159). É possível sugerir que o fenômeno pode ser positivo?

De fato, há contribuições positivas. Mas temos que considerar o debate feminista como algo muito mais profundo do que as ideias apresentadas sob o rótulo do femvertising (2015). Apenas o conceito, a meu ver, não é suficiente para a apresentação de uma perspectiva de mudança de cenário social. A proposta dialoga com a superfície, com uma parte da comunicação estratégica das marcas e empresas que pode ser moldada de acordo com as interações sociais e as lógicas de mercado. Efetivamente, é raso e superficial dizer que o femvertising contempla um novo cenário para a mulher nas representações midiáticas comerciais. Cabe ressaltar que, inclusive, já fui entusiasta da estratégia em questão. Dessa forma, é pertinente reforçar que a publicidade corresponde a uma certa superficialidade externa no pensamento mercadológico, enquanto a filosofia empresarial por trás da gestão de uma marca é mais profunda e diversa.

Nesse âmbito, podemos usar como exemplo a marca de absorventes Always. A marca é dona de uma das primeiras campanhas nomeadas de femvertising, intitulada \#Likeagirl ${ }^{2}$ (2015). A campanha critica o significado pejorativo e machista que o termo "como uma garota" ganhou ao longo da história. Perfaz o debate feminista de que o sentido de ser mulher em nossa sociedade foi construído e é considerado inferior e sinônimo de fraqueza. Isso condensa, inclusive, o debate central das discussões de gênero, isto é, a compreensão de gênero enquanto construção social (Butler, 2008). Usando meninas e depois jovens mulheres - grupos de prospecção e interesse do produto -, a campanha faz uma espécie de experimento social e demonstra que mulheres e homens reproduzem esses discursos. Trata-se de uma mensagem positiva, pedagógica e de fácil assimilação, que dialoga com o sentido de feminismo de mercado. Vou refutar a ideia de femvertising $e$ passaremos a usar o feminismo de mercado como percepção e linha teórica a seguir.

Uma das questões que surgem no cerne desse debate é: será que, ao dar "visibilidade" a essas questões, as empresas parecem "se livrar" de uma reflexão e de uma análise real sobre os temas propostos pelos feminismos, especialmente aquele pautado na segunda onda, nos quais se questiona onde estariam as mulheres nos processos e cargos de decisão? Quantas mulheres realmente participam dos critérios e escolhas empresariais, tomando decisões? Afinal, lugar de mulher é onde ela quiser? Ao se tratar do tema para fora, resolve-se a questão da mulher no mercado de trabalho? A resposta é não.

Se, por um lado, a lógica do feminismo enquanto mercadoria segue uma perspectiva que dialoga com o capitalismo transestético, apresentado por Lipovtesky e Serroy (2015), ao embelezar narrativas e embrulhar conceitos complexos esvaziados, por outro, observo no trabalho de Eva Illouz (2011) os fundamentos para incorporação e recepção aprazível dessa mensagem "positiva" e palatável de um feminismo pronto para o consumo, o capitalismo afetivo.

Illouz (2011) defende que o capitalismo afetivo seria a base para a formação de novas formas de sociabilidade imbricadas no entrelaçamento dos discursos e práticas econômicas associadas à afetividade, que projetam uma nova lógica do capitalismo contemporâneo. Com efeito, há o impulsionamento de uma perspectiva alternativa ao consumo convencional no pensamento capitalista, que fomenta uma cultura afetiva altamente especializada em um nicho de consumidores.

\footnotetext{
${ }^{2}$ Vídeo campanha \#Likeagirl. [https://www.youtube.com/watch?v=XjJQBjWYDTs - acesso em: 01 de Jun. de 2018].
} 
Illouz (2011) questiona o equilíbrio nas concepções do mercado e do afeto na perspectiva ambivalente entre mercado e afetividade e deixa clara a sua tendência na crença de que a lógica mercadológica estaria fazendo com que as interações afetivas fossem menos "românticas" ${ }^{3}$ e mais econômicas.

O trabalho de Illouz (2011) se aproxima do meu desconforto em torno do feminismo enquanto mercadoria, no qual a comoditização é a lógica econômica e o feminismo a lógica afetiva dos valores, da política e da luta por direitos. Nesse sentido, haveria um embelezamento dos discursos $e$ a incorporação de uma narrativa afetiva para conquistar novas consumidoras $e$ apresentar uma aparente mudança de paradigma social da mensagem publicitária.

Dessa forma, torna-se pertinente ressaltar que é possível sugerir que muitas marcas $e$ empresas acabam seguindo os temas e debates em alta no âmbito social sem realmente refletir sobre os assuntos e suas implicações, seguindo uma lógica econômica e mercantil. Ou ainda: o fazem sem a busca de um embasamento especializado, como são exemplos as consultorias de comunicação autointituladas feministas - tais como o Think Olga, Think Eva ou 65/10. Essas, por sua vez, são mais um elemento dentro do sistema capitalista e neoliberal que propõem, no entanto, o investimento da visão e da fala de mulheres em um campo de saber e de negócios que lhes é historicamente negado $e$ em que as mulheres foram - e ainda são- silenciadas. Isto é, uma visão necessária.

Obviamente, precisamos pontuar que o objetivo das marcas e empresas, de forma geral, é o aumento de lucro, e não a reflexão sobre a lógica das relações sociais de poder. Não posso ser ingênua quanto a isso. Há, certamente, incoerências e incongruências no uso das pautas de cunho social, como é exemplo o uso de estratégias de monetização em nichos de mercados demarcados por questões sociais. Exemplos desses processos seriam o pinkmoney ${ }^{4}$ e o blackmoney $^{5}$, que dialogam com a comoditização das agendas de movimentos sociais identitários, bem como a observação de estratégias como o diversitywashing ${ }^{6}$. Será que poderíamos realmente sugerir uma preocupação do mercado com as pautas desses movimentos? Provavelmente não, ao menos numa maioria dos casos.

Esse papel certamente continuará sendo dos movimentos feministas, da sociedade civil e de movimentos sociais localizados, na prática da velha vigilância (Beauvoir, 1970), a partir de uma agenda anticapitalista e antirracista. Portanto, na inescapável promoção de uma cultura de consumo, seria possível falar de consumo consciente? Voltaremos a esse debate adiante. É pertinente observar, neste instante, que algumas nuances desse papel vigilante desempenhado pela sociedade e pelos movimentos sociais gera - e gerou - uma maior atenção a essas pautas adotadas pelo mercado.

Segundo a Organização McKinsey \& Company ${ }^{7}$ (2018), em pesquisa sobre diversidade e lucratividade das empresas, ignorar a diversidade "atrapalha os lucros". A pesquisa ainda demonstra que as empresas com diversidade de gênero apresentam cerca de $15 \%$ de chances a mais de ter rendimentos acima da média.

\footnotetext{
3 Para Illouz (2011), o romantismo foi uma das apropriações pela indústria cultural, advinda da era burguesa em sua formação em meados do século XX. Sua fase inicial foi caracterizada pelos princípios da espiritualidade e patriarcalidade. Após a ascensão indústria cultural, passou se manifestar, na maturidade, de forma individual e hedonista, através da exploração pelo mercado. A autora complementa que "o consumismo conferiu significados e prazeres congruentes, em vez de antitéticos à fenomenologia do amor romântico" (2011:94).

4 Termo usado para caracterizar a monetização e comercialização de produtos voltados para o público LGBTI+.

5 Termo ressignificado pelo movimento negro com o intuito de promover o consumo de produtos e serviços produzidos e vendidos por pessoas negras, incentivando o público para a consciência social e racial, econômica e financeira.

${ }^{6}$ O termo surgiu como um desdobramento do "greenwashing"- lavagem verde, em português - e designa o processo de uma empresa empregar práticas ecologicamente corretas ou sustentáveis, quando, na verdade, faz apenas mudanças superficiais e consideradas de fachada, sem adotar medidas ecologicamente corretas em sua lógica de produção. Recentemente, foram adotadas abordagens semelhantes no que diz respeito ao tema da diversidade; isso, denominou-se "diversitywashing".

7 A diversidade como alavanca de performance [https://www.mckinsey.com/business-functions/organization/ourinsights/delivering-through-diversity/pt-br\# - acesso em: 13 jan. 2020].
} 
Esse movimento pode ser alinhado ao pensamento de Harvey (2011) na perspectiva da "destruição criativa", que rompe com modelos existentes de produção, nesse caso, produção publicitária e gestão empresarial, e constrói uma nova lógica narrativa, fazendo constantes ajustes discursivos para acompanhar as mudanças e a complexidade do escopo social. Vale ressaltar que apesar do texto de Harvey não citar diretamente, o termo foi cunhado pelo economista Joseph Schumpeter, em 1942, em sua obra Capitalismo, Socialismo e Democracia (1984) e se referia ao papel do "empresário empreendedor" no processo de desenvolvimento do capitalismo. Para Harvey (2011:195), "esclarecer o enigma do capital, tornando transparente o que o poder político sempre quer manter opaco, é crucial para qualquer estratégia revolucionária".

Há uma clara ambivalência nesse debate, e talvez a questão central esteja atrelada ao uso que se faz dos feminismos numa lógica mercadológica. É preciso transbordar a publicidade e pensar mais na gestão empresarial e da marca. Numa cultura empresarial que questione a situação das mulheres. Cada dia mais, esses processos estão imbricados e alinhados entre si. Se o processo não for mais profundo do que a publicidade, a pauta feminista palatável teria sido apenas incorporada pelo mercado, que tem ganhado bilhões de retorno do investimento publicitário. Há saídas possíveis? Depende do ponto de vista.

O meu objetivo nesta reflexão não é explorar as teorias do consumo, mas mapear alguns apontamentos e debates que serão importantes para a compreensão do tema. Dessa forma, entendemos o consumo como uma dimensão preponderante no relacionamento social, que vai muito além do ato de compra de bens e serviços, está atrelada a um processamento de informações que associa significados sociais, culturais e relacionais ao produto comercializado. Para Douglas e Isherwood (2006), o consumo é parte integrante do sistema social e da necessidade de mediar o relacionamento entre os sujeitos por meio de produtos, constituindo um ritual cuja função é dar sentido ao processo de trocas e aprendizados, sendo que os produtos são assessórios desse ritual social.

Para Canclini (1995), o consumo pode ser um aspecto preponderante no exercício da cidadania, na ótica do poder de reflexão que ele pode suscitar nos consumidores. O autor afirma que

homens e mulheres percebem que muitas das perguntas próprias dos cidadãos - a que lugar pertenço e que direitos isso me dá, como posso me informar, quem representa meus interesses recebem sua resposta mais através do consumo privado de bens e dos meios de comunicação de massa do que nas regras abstratas da democracia ou pela participação coletiva em espaços públicos (Canclini, 1995:37).

As afirmações de Canclini somam-se às concepções acerca do caráter pedagógico da mídia comentado por Louro (2008). Bourdieu (2003), por sua vez, argumenta que os objetos têm o poder de induzir, por associação, qualidades que representam simbolicamente o consumo de determinados produtos a algum grupo social ou causa. $\mathrm{O}$ autor defende que essas distinções são estruturas que servem como princípios geradores e organizadores que hierarquizam práticas $e$ representações sociais.

Canclini (1995) reflete, ainda, sobre como o consumo pode alterar as formas de exercer cidadania e, outrossim, como ele como assume papel central na construção dos sujeitos. $\mathrm{O}$ autor defende que é necessário desconstruir os julgamentos atrelados ao consumo e às práticas de consumo em sociedade. Geralmente, as práticas do consumidor são vistas como supérfluas e irracionais, $e$ as questões ligadas à cidadania são reduzidas a questões de ordem política. $\mathrm{O}$ autor afirma também que só será possível reconhecer os novos cenários de constituição social aproximando a cidadania do consumo e da comunicação de massa. Nesse raciocínio, o consumo poderia ser reconhecido também enquanto habilitador de cidadania. E por que não poderia, assim, atender às demandas de visibilidade e pertencimento? Ao observar os pontos previamente elencados, não seria um erro excluir completamente o debate feminista da visibilidade midiática? Acreditamos que seria importante compreender a construção desse diálogo, para, quem sabe, sugerir possíveis caminhos. 


\title{
O feminismo de mercado: mapeando caminhos
}

Os discursos feministas vêm sendo utilizados e ressignificados na mídia. Se outrora era combatida a legitimidade do discurso feminista, agora se tenta canalizar suas principais pautas anexadas a marcas e produtos. Boltanski e Chiapello (2009) argumentam que as mudanças ideológicas acompanharam as recentes transformações do capitalismo, entre as quais podemos incluir os debates feministas. Os autores defendem, ainda, que o capitalismo exibe a insólita capacidade de apropriar-se das manifestações ideológicas e pautas sociais que, a princípio, seriam opostas à sua lógica, num denominado "novo espírito do capitalismo". Sobre isso, Nancy Fraser ressalta que

\begin{abstract}
o capitalismo se refaz periodicamente em momentos de ruptura histórica, em parte recuperando as tendências de crítica dirigidas contra ele. Em tais momentos, elementos de crítica anticapitalista são ressignificados para legitimar uma forma nova e emergente de capitalismo, que assim se torna dotada da mais alta significação moral necessária para motivar novas gerações a arcar com o trabalho inerentemente sem sentido de acumulação infinita (Fraser, 2009:24)
\end{abstract}

Mary Douglas e Baron Isherwood (2006) argumentam que uma racionalidade sociológica move o consumo. A autora e o autor compreendem o consumo como atividade cultural fundamental na organização social. Dessa forma, os sistemas de valores culturais na contemporaneidade mudaram de tal modo que os marcadores identitários tradicionais perderam espaço para o consumo enquanto marcador central na compreensão da personalidade $e$ individualidade. Assim, a lógica de produção e consumo estaria pautada na atomização do mercado, isso é, na reformulação do estado e na supervalorização do indivíduo como o responsável pelo seu próprio sucesso (Dardote Laval, 2016). Exemplo disso são os discursos em torno da ideia de "empoderamento feminino".

É nesse contexto que a publicidade investe suas estratégias, através de discursos e peças publicitárias que revestem os produtos e serviços de valores e atitudes ligados ao sujeito. Entendo a publicidade enquanto um processo comunicacional que interfere numa prática social, a qual influencia o comportamento e os modos de vida dos indivíduos na contemporaneidade e opera, também, enquanto agente pedagógico (Louro, 2008). Essa reflexão dialoga com a proposta do capitalismo transestético (Lipovetsky; Serroy, 2015), em que, como explicado, a estetização funciona como estratégica de sobrevivência. Esse processo de embelezamento por que os feminismos têm passado numa proposta mais mainstream e de popularização parece ter se tornado uma útil ferramenta para a ação, para a análise, e, ainda, para a crítica de uma realidade na qual as empresas e marcas são protagonistas. Isso tudo em um tempo no qual o consumo é especialmente caracterizado pelas narrativas e propostas efêmeras, pela obsolescência programada de bens de consumo e pela espetacularização das relações econômicas, políticas e sociais.

Robert Goldman (1992) publicou o livro Reading adssocially, no qual apresenta o termo commodity feminism, em tradução literal, feminismo de mercadoria, no qual opto por chamar de feminismo de mercado. Apesar de introduzido nos anos 1990, o termo não foi debatido no âmbito dos estudos de gênero e midiáticos no Brasil. O autor argumenta que o feminismo foi "adotado" pela indústria da publicidade, que o transformou em commodity, em resposta à crescente crítica feminista, durante os anos 1980, pela mídia e pela publicidade. Em contraponto a essa afirmação do autor, Mirian Catterall, Pauline Maclaran e Lorna Stevens (2015) expõem que os mercados, bem como a publicidade, sempre tiveram proximidade com todas as ondas do movimento feminista. Importa dizer que as ondas foram designadas e separadas em períodos históricos datados pela movimentação de mulheres que se organizaram, ao longo da história, de maneiras distintas, em momentos igualmente diversos. Cronologicamente, houve acúmulos de reivindicações, pautas e conquistas separadas no que conhecemos por ondas feministas.

Catterall, Maclaran e Stevens (2015) defendem que, já na primeira onda do movimento, com as sufragistas, o marketing era visto como uma força positiva no auxílio da divulgação das ideias e campanhas, por exemplo, havendo encontros marcados em grandes lojas de departamento da 
época. Já o feminismo da segunda onda foi fortemente influenciado por discursos antimarketing $e$ antimercado, sob a influência de textos de importância para o movimento, como é exemplo a Mística Feminina de Betty Friedan (1963), dentre outros.

Hamlin e Peters (2019) afirmam que essas relações entre os feminismos e a publicidade "foram mais contenciosas entre os anos 1960 e 1980, período que caracteriza a segunda onda do movimento". Já sobre o feminismo de terceira onda, a autora sustenta que foi descortinada e a ideia de feminismos plurais, para além da sua relação com sistemas de opressão distintos, como raça/etnia, gênero, classe. Catterall, Maclaran e Stevens (2015) ponderam, ainda, que a revolução foi cooptada pelo mercado e argumentam que "nos anos 90, o capitalismo, sob o disfarce do marketing pós-moderno, descobriu muitas novas oportunidades de mercado ao responder à celebração de diferença que a virada cultural trouxe" (2015:1733).

Goldman (1992) pensa, também, que a publicidade e as estratégias mercadológicas, aparentemente de causas associadas às ideias feministas, nasceram como uma tentativa de incorporar o poder cultural $e$ as ideias do feminismo à publicidade, ao mesmo tempo em que domestica (Foucault, 1979) a crítica do próprio movimento feminista ao mercado. Para o autor, essa foi uma forma de apaziguar o descontentamento das mulheres com as imagens de mulheres magras, jovens e hipersexualizadas.

Isso pode ser especialmente percebido em anúncios que tentam articular uma aproximação entre a feminilidade enfatizada e hegemônica (Connell, 2005) e o que é decodificado como ideias feministas, tais como: independência financeira, sucesso profissional, liberdade e empoderamento. Segundo Goldman (1992), essa "nova mulher" apresentada em muitos anúncios foi aparentemente "empoderada" e, assim, contemplaria as visões feministas pela qual tanto se lutou (Goldman, 1992). Na visão do autor, essa é uma proposta falaciosa, superficial e alinhada aos propósitos do capitalismo.

Goldman (1992) realizou um estudo sobre a propaganda dos anos 1980 e a relação do uso do feminismo e seus valores para os propósitos do marketing, que transformaram um movimento político e social em mais uma tendência. Ao usar a pauta feminista como valor social que pode ser comprado junto com um produto que simula a independência feminina, os objetivos sociais do feminismo são transformados em "estilos de vida" para consumidoras (Goldman, 1992). Cabe ressaltar que as narrativas encontradas pelo autor na época estudada se distanciam um pouco da realidade que observamos hoje na representação feminina na publicidade, mas o debate em torno do uso dos feminismos, a nosso ver, está preservado. Nesse sentido, o autor enxerga a produção de um "falso feminismo" empacotado para agradar e se adequar ao mercado. Um feminismo palatável, de fácil assimilação, mas pobre de crítica e politicamente frágil.

McRobbie (2009) defende que essa narrativa midiática reproduz formas mais "toleráveis" de representações de teor emancipatório e progressista, que são empreendidas, de forma geral, pelos feminismos perpetrados especialmente para a juventude. A autora corrobora com Goldman quando afirma que ideias atreladas ao empoderamento feminino têm sido ofertadas às mulheres "como uma espécie de substituto à política e transformação feminista" (Hamlin; Peters, 2019). Por isso, faz-se pertinente compreender o cerne do conceito de feminismo de mercado.

A acepção do conceito de feminismo de mercado foi realizada por Goldman (1992) sob o termo "fetichismo da mercadoria", cunhado por Karl Marx na obra O Capital, publicada em 1867. Marx (2005) conceitua o feitichismo da mercadoria enquanto o caráter que os produtos possuem, dentro do sistema capitalista, de ocultar as relações sociais de exploração do trabalho, sedimentando-se, por conseguinte, em toda a sociedade. No cerne dessas relações sociais, a obtenção do lucro fica por parte de quem detém os meios de produção, nesse caso, as marcas e os anunciantes associados à publicidade. Para Marx (2005), o fetichismo é uma relação social entre pessoas mediada por produtos, coisas e objetos. Como resposta a esse processo, é possível ter a sensação de uma relação direta com os produtos, e não entre as pessoas. Atrelada a esse conceito, ressalto a forte crítica do movimento e das teorias feministas ao capitalismo e à sua lógica de produção, especialmente em no que diz respeito à distribuição desigual do poder de trabalho. É possível perceber essa lógica nas reorganizações e performances das marcas, em que os signos são 
mobilizados para instaurar essas narrativas contemporâneas que retiram o produto de seu uso factual para processos elaborados de ressignificação com a prática social.

Diversas autoras e feministas denunciaram o sistema capitalista e sua prática de exploração naturalizada, legalizada e legitimada na construção de sociedade na qual vivemos. De fato, ao anexar esse debate ao feminismo, é possível perceber que o capitalismo, ao longo da história contemporânea, instrumentalizou as diferenças históricas e sociais, negando direitos e cidadania às mulheres, institucionalizando as diferenças entre o público e o privado/doméstico (Okin, 2008), domesticando a mulher através de trabalho não pago e categorizando o trabalho produtivo e não produtivo. Não seria, então, um contrassenso usar discursos feministas na publicidade? Numa visão mais superficial, poderíamos responder que sim.

Na década de 1960, o movimento feminista formulou uma crítica radical às estruturas sociais, propondo embates pertinentes junto às vertentes liberais do movimento de mulheres, bem como a respeito da invisibilidade e o desprezo à questão das mulheres no debate marxista. Nesse âmbito, através dessa crítica, foi desenvolvido o conceito de patriarcado como parte da formação social em que os homens detêm o poder $e$ as mulheres são subalternizadas. Instaura-se, assim, a divisão sexual do trabalho, que destina aos homens as tarefas produtivas, valorizadas e remuneradas, no âmbito público. As mulheres estariam confinadas às tarefas reprodutivas e domésticas (Okin, 2008).

$\mathrm{O}$ desafio com que o feminismo se deparou foi o de entender como a dominação masculina (Bourdieu, 2007) e as relações de poder, no que toca as relações de gênero, se encaixam nessa lógica, explorando os vínculos familiares e de gênero, nas quais a distribuição desigual dos ditos papéis sociais é central na estrutura capitalista. Para Nancy Fraser (2016), "em uma cruel reviravolta, temo que o movimento para a libertação das mulheres tenha se enredado em uma ligação perigosa com esforços neoliberais para a construção de uma sociedade de livre-mercado" (Fraser, 2016: s/p).

Rosalind Gill (2007) também refletiu sobre a mudança na representação de mulheres nas imagens publicitárias com o uso de discursos feministas e situa essa prática em um discurso pósfeminista. A autora relata que estamos vivenciando uma "cultura midiática pós-feminista". Dessa forma, é pertinente compreender o pós-feminismo. Não tenho a intenção de desbravar o conceito, que é complexo e ambíguo. Para algumas correntes dos feminismos, o pós-feminismo estaria alinhado ao discurso do pós-modernismo. Essa leitura baseia-se no fato de que o objetivo pósfeminista estaria calcado em desconstruir/desestabilizar o gênero enquanto categoria fixa e imutável, debatido no final dos anos 1960 entre as chamadas teóricas da "diferença", tais como Julia Kristeva e Hélène Cixous (Macedo, 2006).

Já as outras correntes do feminismo afirmam que essa aproximação com pós-modernismo é problemática e perigosa. Argumentam que o pós-feminismo é visto incorporado ao feminismo de "terceira onda", que se identificaria com uma agenda liberal (ou neoliberal) $e$ individualista, deixando de lado a característica de pautas coletivas e políticas. O ponto de maior crítica nessa corrente pós-feminista é sua consideração de que as principais reivindicações de igualdade e equidade entre homens $e$ mulheres foram atendidas e que o feminismo deixou de representar adequadamente as preocupações e anseios das mulheres na contemporaneidade (Macedo, 2006).

O pós-feminismo certamente não é um conceito consensual, e não é minha intenção debatêlo neste texto. Nas últimas três décadas, o pós-feminismo foi entendido como uma mudança de paradigma histórico após o auge da segunda onda do feminismo, uma espécie de reação contra o feminismo, uma nova perspectiva epistemológica no âmbito dos debates feministas. Para Gill (2007), pós-feminismo atende a uma série de temas que dialogam com o individualismo, a escolha e o consumismo.

Showden (2009) defende que o pós-feminismo seria o culpado pela despolitização de muitos dos objetivos políticos conquistados durante a segunda onda, concentrando-se no individualismo, $e$ não em uma ação crítica e política coletiva. O processo de comoditização dos feminismos na publicidade dos anos 1980 nos parece ter sido uma reação capitalista à agenda da segunda onda, que olhava para a questão da igualdade entre homens e mulheres como um fenômeno político, no âmbito da esfera pública. A publicidade se apropria disso para lançar as bases, para naturalizar, 
criar o senso comum (Bourdieu, 2003) que sustenta até hoje essa nova forma de pautar bandeiras feministas.

O conceito de pós-modernidade, nesse debate, é caracterizado pelo processo de globalização e pelo domínio do sistema capitalista. Todavia, minhas impressões dialogam com Bruno Latour (1994), o antropólogo que desenvolveu uma crítica à ciência e ao seu processo de construção. Segundo o autor, a modernidade nunca existiu,logo, não há como se opor a ela a partir da ideia de pós-modernidade.

Latour (1994) defende que boa parte das definições sobre modernidade estão associadas a um debate de ordem temporal, que tende a apontar um nova ordem, rupturas ou mesmo aceleração do tempo em (r)evolução. Define-se, assim, um passado antiquado e estável. A crítica do teórico se estabelece sobre o binarismo científico segundo o qual a natureza seria objetiva e a sociedade, subjetiva; o autor defende a existência de híbridos. Ao questionar as ideias rígidas propostas pela acepção de modernidade, o pesquisador afirma que concepção seria uma abstração. De forma prática, para o pensador, existem complexas redes que são emaranhadas, complexas e híbridas.

Nesse âmbito, em torno da crítica às ideias de modernidade e pós-modernidade, ou mesmo da não modernidade, as reflexões elencadas por Anne McClintock (2010) questionam o uso corrente do prefixo "pós" para assinalar uma pretensa crise na evolução histórica linear, debatida constantemente pelas ciências humanas e sociais na contemporaneidade. A autora, em suas reflexões, debate a respeito do sistema colonialista vigente na sociedade, indagando a respeito da ideia por trás do uso do "após", em relação ao pós-colonialismo. Além disso, afirma que se trata de um paradigma que não pertence ao passado, que não deve ser pensado de forma temporal $e$ cronológica. Essa concepção daria a impressão de uma permanência e não de finitude de um ciclo. Uma ideia de espacialidade dúbia e que inviabiliza outras cronologias e perspectivas.

Com efeito, Bhabha (2007) complementa que, no âmbito das teorias feministas, a ideia de modernidade e de colonialismo produzem um sentido revisionário, desafiando perspectivas etnocentradas, ao se integrarem novas narrativas, vozes e "histórias dissonantes" dos sujeitos subalternizados (2007:23).

Numa concepção alinhada à terceira onda do feminismo, há a percepção de que existem diversas versões sobre o feminismo e suas vivências, dessa forma, a práxis e a vivência dos feminismos deveriam se pautar pelas diversas experiências das mulheres. Nessa abordagem, o pósfeminismo não é encarado como o fim do feminismo, mas como um intenso processo de transformação. Assim, o pós-feminismo pode ser entendido também como um termo que abarca diversos feminismos e que convida a refletir e debater as contradições e oportunidades que as mulheres enfrentam na contemporaneidade (Macedo, 2006). E é nessa corrente que invisto meus apontamentos. Pensando o pós-feminismo num quadro mais amplo, a visibilidade e poder da mídia são vistos de forma positiva. A prática de consumo pode ser um lugar para novas formas de retratar mulheres, e não unicamente um espaço de discursos e representações misóginas (Barreto Januário, 2016). Mas um debate tão complexo não pode ser reproduzido com simplicidade.

Com efeito, há correntes que enxergam uma lógica positiva no uso de valores e discursos feministas na propaganda e no marketing. Linda Scott (2000) defende que o feminismo e o capitalismo podem não ser incompatíveis, afirmação complexa a nosso ver. A autora alega que uma representação positiva e atual da mulher auxiliaria no processo de compreensão do poder e da emancipação da mulher na contemporaneidade. E defende que a opressão das mulheres pela dominação masculina ocorre também em outros sistemas econômicos.

Na mesma perspectiva apresentada por Scott (2000), Megan Sirr (2015) argumenta que esse tipo de representação mais positiva poderá, a médio e longo prazo, beneficiar as mulheres se houver uma prática mais recorrente no mercado, estimulando versões mais realistas e elogiosas às mulheres. Para a autora, que apresenta uma leitura mais cética do que Scott (2000), seria uma mudança de paradigma da representação dominante sobre as mulheres e seus corpos, o que poderia significar uma espécie de introdução ao feminismo e suas pautas. Sarah Banet-Weiser (2012) argumenta a existência de um paradoxo e uma certa ambivalência nas estratégias publicitárias e do marketing, mas defende que é muito fácil descartar exemplos positivos ao elencar 
apenas a lógica capitalista como argumento de exclusão. A autora salienta a necessidade de uma análise mais aprofundada sobre se o discurso é superficial e perigoso para o feminismo ou se, por outro lado, pode ser inspirador para as mulheres.

É possível perceber, ao longo do debate, que é difícil rotular o feminismo de mercado como simplesmente positivo ou negativo. O olhar maniqueísta sobre essas questões pode esconder diversas nuances e camadas da análise crítica do tema. Banet-Weiser (2012) reflete também que, no processo de popularização das pautas feministas, é necessário nos envolvermos em possíveis ambiguidades complexas das quais a mídia faz parte. Se, por um lado, as mulheres hoje recebem mensagens publicitárias de que podem fazer qualquer coisa, "ser o que quiserem" $e$ mover estruturas, por outro lado, seus corpos continuam sujeitos à vigilância da ditadura da beleza (Wolf, 2009). A indagação que fica é: será que esse discurso incorporado e ratificado pela publicidade de "ser e estar onde quiser" leva a algum lugar? Ou seria um "não lugar"?

O feminismo contemporâneo, cada vez mais presente na esfera digital, tem sido por vezes chamado de quarta onda. Teóricas que dialogam sobre a quarta onda concordam que a pluralidade constitui e demarca os interesses, demandas e expressões dos movimentos feministas. Nesse contexto, a reconstrução transdisciplinar de uma nova onda do feminismo passou a ganhar força nos debates apoiados em estratégias de ação inovadoras e associadas às transformações vivenciadas na atualidade. Matos (2010:81) teoriza a quarta onda do feminismo e argumenta que esse novo marco traz "os desafios da horizontalização dos movimentos feministas e da construção coletiva do diálogo intercultural e intermovimentos". A autora debate as questões associadas às pautas plurais dos feminismos, especialmente na América Latina.

Para Kira Cochrane (2013), o feminismo da quarta onda é também caracterizado pelo uso da tecnologia, especialmente pelas militâncias ciberfeministas e pelo uso das mídias sociais no desafio de denunciar a misoginia. Mulheres em todo o mundo vêm utilizando as mídias sociais para denunciar, esclarecer e promover o debater em torno de diversas especificidades e nuances das opressões de gênero. No entanto, pergunto-me mais uma vez: que mulheres? Teríamos voltado a analisar conquistas, importantes, a nosso ver, que só alcançam algumas mulheres com determinados privilégios?

Sobre isso, parece-me pertinente pontuar a reflexão sobre os conceitos de "mulher" e de "mulheres" de Chandra Mohanty (1984). Para a autora, o conceito de mulher seria relativo ao "outro", seja ele ideológico ou cultural, concebido pelo discurso. Já o conceito de mulheres seria uma referência ao sujeito político, real. Mohanty(1984) destaca, ainda, que o feminismo acadêmico ocidental, de forma equivocada, assumiu no cerne das agendas do movimento feminista um discurso universalista que, de forma homogênea, incluiria "todas as mulheres" numa mesma pauta. Com efeito, seria essa uma visão homogeneizada e que, ao mesmo tempo, banaliza a opressão sofrida pelas mulheres em sua diversidade.

Nessa perspectiva, Gayatri Spivak (2010) constrói uma crítica aos intelectuais e acadêmicos ocidentais. A autora reflete sobre a prática discursiva e a possibilidade de agenciamento do sujeito subalterno pelo intelectual pós-colonial. Spivak argumenta que "[...] no contexto da produção colonial, o sujeito subalterno não tem história e não pode falar, o sujeito subalterno feminino está ainda mais profundamente na obscuridade" (Spivak, 2010:67). A autora conclui que o espaço dialógico de interação jamais é concretizado para o sujeito subalterno.

O mercado, igualmente, tenta homogeneizar essas mulheres. Ao fomentar a quebra do ciclo histórico da representação da mulher abarcada pela misoginia, o processo de uso de valores feministas surge como uma tardia, porém necessária, releitura dos discursos circulantes da publicidade e do marketing, observando que as velhas performances de gênero (Butler, 2008) não irão funcionar com a nova geração de mulheres. Com a efervescência das novas tecnologias de comunicação $e$ o intenso uso da internet e suas ferramentas, os feminismos ganharam um aliado no processo de informação, o ciberativismo (Furini; Malini; Antoun, 2016), como vem sendo chamado o ativismo nas plataformas digitais.

A mola propulsora dessas novas prerrogativas nas estratégias publicitárias foi abarcada pelo discurso do empoderamento. O termo significa, de forma sucinta, dar poder. Os processos de empoderamento estão ligados à concepção e socialização das relações de poder em sistemas 
participativos (Gutiérrez e Lewis, 1999), em distintas áreas de atuação social, cultural e política. A palavra vem sendo amplamente utilizada em diferentes campos de saber. $\mathrm{O}$ termo ganhou notoriedade social na égide do movimento de luta dos direitos das mulheres, LGBTQ e igualitários, debatidos no âmbito acadêmico, ganhando grande visibilidade no agendamento midiático e nas estratégias ativismo de marcas, no qual os consumidores são convidados a defender valores $e$ princípios juntamente com uma marca, agregando valor ao seu DNA (Mukjerjee; Banet-Weiser, 2012).

O empoderamento feminino vem sendo debatido na academia e pautado na militância feminista como processo de libertação das mulheres das amarras, invisibilidades e silenciamentos promovidos pela opressão de gênero e dominação masculina (Gutierrez; Lewis, 1999). Mas será que se pode falar em empoderamento feminino e pautas feministas no que vem sendo promovido como feminismo nos meios mainstream? Parece-me evidente que as narrativas do feminismo de mercado, transmitidas através de veículos linguísticos e imagéticos, construídos para dar conta de uma nova estratégia do marketing, é excludente e incipiente no que compreendemos por uma visibilidade de feminismos mais interseccionais ${ }^{8}$ (Crenshaw, 1990) e da multiplicidade de sujeitos.

Com efeito, acredito que não há como escapar ou retroceder nesse processo de mercantilização. Os feminismos tornaram-se mercadoria, fato. E agora? A meu ver, fomentar um uso consciente e coerente, mesmo na lógica da mercadoria, seja na utilização da publicidade, seja do mercado junto às pautas feministas, é certamente complexo (Banet-Weiser, 2012). Por isso, fazse necessário atentar para algumas questões que ultrapassam a publicidade.

Perez e Trindade (2016) argumentam sobre a profundidade na junção entre o consumo e a construção de uma sociedade mais igualitária, considerando os processos de midiatização dos consumos $e$ a multiplicidadede sujeitos, públicos e pautas. A autora e o autor dialogam com as nossas ideias acerca do feminismo enquanto mercadoria nesse processo de midiatização, ao afirmarem que

[...] essa diversidade dos sujeitos é conveniente ao sistema capitalista ou prejudicial à construção de uma sociedade mais igual, buscamos mostrar que essa diversidade de valores socioculturais, manifestada nas tendências de consumo, não é harmônica e revela os conflitos e dilemas da própria sociedade capitalista, cuja institucionalização se dá por meio das práticas sociais ritualizadas no cotidiano dos sujeitos consumidores tendo a mediação das marcas como forte expoente nestes processos de apropriação (Perez; Trindade, 2016:4).

Dessa forma, é possível sugerir que o consumo também pode ser representação (Canclini, 1995), também pode atender demandas de visibilidade e pertencimento. Assim, pergunto novamente: não seria um erro excluir completamente o debate feminista da visibilidade midiática? Em partes, sim.

No âmago das reflexões previamente evocadas, chamo a atenção para três pontos que me parecem centrais numa análise da produção midiática e mercadológica que dialogue com a construção de uma equidade de gênero no mercado e para um feminismo de mercado ao qual poderia chamar de "consciente": 1. Histórico de comunicação da empresa; 2. Gestão empresarial junto à pauta da equidade de gênero; 3 . Empreendedorismo feminino e feminista.

É preciso dar a conhecer profundamente o histórico de comunicação da empresa, vislumbrando pontos de rupturas e continuidades de mensagens publicitárias misóginas e sexistas.

\footnotetext{
8 Sobre interseccionalidade, importa observar que o termo surge como uma proposta teórico-metodológica, com o intuito de se dar luz ao debate em torno das relações sociais de poder e os contextos em que se produzem as desigualdades sociais e de poder entre os gêneros, bem como as assimetrias socialmente situadas construídas ao longo da história. As diversas teorizações a despeito das interseccionalidades são ponderadas por Adriana Piscitelli (2008), com o objetivo compreender a "multiplicidade de diferenciações que, articulando-se a gênero, permeiam o social" (2008:263). Dessa forma, a autora afirma que conceito teve sua acepção calcada através do uso de diferentes terminologias ao longo da evolução dos debates em torno das questões de gênero e suas diversas intersecções (Butler, 2008) de marcadores indenitários e sociais. A autora defende, ainda, que algumas teóricas trabalham também com termos como "categorias de articulação", "simultaneidade", "matriz de dominação", ou, em alguns casos, utilizam mais de uma dessas categorias concomitantemente (Brah, 2006). Somado a isso, outro termo que costuma ser utilizado para remeter a questões semelhantes é o conceito de interlocking oppressions (Hill Collins, 2000).
} 
Dessa maneira, promover-se-iam, a longo prazo, a permanência e prática de gestão dos discursos que emergem da comunicação da marca, como é o caso de quando a mobilização em torno do tema passa. Já na gestão interna, acrescer-se-iam a pauta da equidade de gênero e a relação do trabalho e das mulheres.

Como explicitei anteriormente, a lógica capitalista aprisionou mulheres no âmbito privado/doméstico (Okin, 2008) e lhes negou o trabalho remunerado e salários equivalentes ao longo da história. As gestões empresariais precisam ser coerentes em relação ao direito das mulheres, às situações de assédio e aos salários igualitários, já que se utilizam das premissas feministas como estratégia de diálogo com seu público. Isto é, as empresas precisam ter como filosofia empresarial o respeito às pautas feministas que dizem defender, especialmente no que concerne às lógicas de produção e trabalho das mulheres. Um exemplo dessa aplicabilidade têm sido as tentativas da Magazine Luiza junto a funcionárias e vítimas de violência doméstica9 .

Ao se investir em uma estratégia de comunicação que legitima a imagem feminina enquanto agente de sua própria emancipação, inspirando representações positivas e reais das mulheres (Banet-Weiser, 2012), é possível promover, a longo prazo, uma nova forma de visibilidade do feminino na sociedade. Ao estender essas premissas ao marketing e ao mercado, acreditamos que se pode vislumbrar mudanças no cerne dos modos de produção e em parte considerável da cadeia produtiva que envolve o trabalho das mulheres.

Por fim, o impulsionamento da publicidade e das estratégias alinhadas ao feminismo de mercado tem auxiliado no fortalecimento de empresas, marcas $e$ iniciativas de mulheres $e$ feministas, especialmente no mercado informal. O surgimento de um consumo solidário entre mulheres, incorporado a causas e associado aos "novos" sujeitos que detêm os meios de produção - e não mais apenas grandes corporações - sugere-nos caminhos outros que necessitam de atenção $e$ análise. Essa avaliação insere-se na perspectiva de um empreendedorismo feminino e feminista, tema que precisa sair de uma premissa romantizada, facilmente advinda de uma realidade sobrecarregada e de vulnerabilidade, mas que, em situações diversas, tem conferido resultados importantes na vida de algumas mulheres.

\section{Considerações finais}

No cenário contemporâneo, no qual a comunicação, os feminismos e as novas tecnologias vivem momentos de grande efervescência, é possível identificar importantes mudanças nas formas de relação entre os atores sociais, o consumo e os processos de representação midiática.

A academia garantiu aos feminismos um espaço para questionar a opressão nos mais variados campos de saber, um deles é a Comunicação. Os estereótipos e a naturalização da objetificação das mulheres, antes incontestáveis, passaram a ser denunciados e questionados. Como consequência desse novo comportamento, surge uma lógica de mercado que visa ocupar um novo cenário no âmbito da comunicação e da mídia.

Se, por um lado, encontramos o ceticismo e desconfiança desses usos e estratégias (McRobbie, 2009) há, também, entusiastas (Scott, 2000) e correntes que exaltam a ambivalência e complexidade do tema (Gill, 2007; Banet-Weiser, 2012). Acredito que esse seria o ponto de partida para pensar a saída de um uso superficial, raso e perigoso para o manejo das estratégias de publicitação em torno do feminismo de forma consciente na promoção de mudanças na imagem que as mulheres veem de si mesmas na mídia e também de bons exemplos em espaços de liderança. Apesar de existir uma visão positivista de que "temos o poder de denunciar e questionar" tais práticas sexistas, é preciso pensar sobre o privilégio das mulheres que podem fazê-lo. Afinal, o acesso a determinadas ferramentas e discursos não chega a todas as mulheres. Existem questões de classe, assimetrias sociais, raciais e privilégios que precisam ser ponderadas nesse debate. E essa problemática está muito além de pensar que as estratégias se concentram apenas na superficialidade externa da publicidade e marketing das marcas.

\footnotetext{
9 App do Magazine Luiza ganha botão para denunciar violência contra mulheres. Época Online [https://epocanegocios.globo.com/Empresa/noticia/2019/03/app-do-magazine-luiza-ganha-botao-para-denunciarviolencia-contra-mulheres.html - acesso em: 05 ago. 2020].
} 
Por fim, vislumbro uma nova forma de usar a publicidade e o marketing em prol de uma popularização que pode ser positiva para a ampliação do debate dos feminismos e na destruição criativa da lógica dominante (Harvey, 2011), visando a reconstrução de uma nova perspectiva na forma de pensar a publicidade e estratégias de marketing abarcadas por pautas de importância social.

Pode-se fazê-lo através de debates e questionamentos de/em lugares onde o feminismo antes não era acessado, em que há uma riquíssima multiplicidade de abordagens e intersecções de feminismos, tão diversos quanto as mulheres. Ao mesmo tempo, todavia, esse é um processo que pode ser, e tem se demonstrado, danoso e contraproducente ao caráter político do movimento, causando um esvaziamento que toma como parâmetro uma discussão superficial e rasa, aprisionada nas amarras nas quais nos encerramos socialmente. São desafios complexos, frutos da massificação de um paradigma que prevê a liberdade de vivências para as mulheres. $\mathrm{O}$ feminismo serve para defender todas as mulheres, inclusive aquelas que não estão contempladas no discurso do "ser e estar onde quiser", e que discordam das pautas feministas. Com efeito, torna-se pertinente acompanhar os desdobramentos e usos da estratégia para uma análise crítica e consciente, aplicando-se critérios de análise mais aprofundados.

Finalizo reafirmando que manter o debate em torno do feminismo de mercado apenas numa ótica dualista que elenca fatores positivos e/ou negativos, acaba por aprisionar o debate que, a meu ver, já foi superado. É imperativo observar outras camadas, o que está no meio, nos entre-lugares, como a proposta de uso consciente de fenômeno inescapável.

$\mathrm{O}$ feminismo de mercado consciente decorre da ideação e prática de estratégias que dialoguem com princípios instaurados no âmago empresarial e DNA da marca. Do uso de pautas verdadeiramente postas em prática por uma filosofia empresarial comprometida. O tema está longe de encerrar uma resposta consensual; são muitas as nuances para fomentar uma utilização consciente de causas sociais pela cultura de consumo. Este é um debate que reclama reflexões e análises de objetos mais aprofundados e da conjuntura histórica para uma fundamentação fidedigna e realista.

\section{Referências bibliográficas}

BANET-WEISER, Sarah. Free self-esteem tools?: Brand culture, Gender, and the Dove Real Beauty Campaign. In: MUKJERJEE, Roopali; BANET-WEISER, Sarah (org.). Commodity Activism: Cultural resistance in neoliberal times. Nova Iorque, New York UniversityPress, 2012, pp.39-56.

BARRETO JANUÁRIO, Soraya. Masculinidades em (re)construção: gênero, corpo e publicidade. Covilhã-PT, LabCom, 2016.

BARRETO JANUÁRIO, Soraya; VELOSO, Ana. O entrelace entre Gênero e Comunicação: uma discussão contemporânea. In: DIAS, Alfrâncio; SANTOS, Elza; CRUZ, Maria Helena (org.). A transversalidade de gênero na produção do conhecimento e nas políticas públicas. Aracaju, SE, Editora IFS, 2017, pp.165174.

BELELI, Iara. Corpo e identidade na propaganda. Revista Estudos Feministas (15), Florianópolis-SC, 2007, pp.193-215.

BRAH, Avtar. Diferença, Diversidade, Diferenciação. cadernos pagu (26), Campinas-SP, Núcleo de Estudos de Gênero-Pagu/Unicamp, 2006, pp.329-376.

BROWN, Wendy. Nas ruínas do neoliberalismo: a ascensão da política antidemocrática no ocidente. São Paulo, SP, Editora Politéia, 2019.

BOURDIEU, Pierre. A distinção. Porto Alegre, RS, Ed. Zouk, 2007.

BUTLER, Judith. Problemas de gênero: feminismo e subversão da identidade. Rio de Janeiro, Civilização Brasileira, 2008.

CANCLINI, Néstor García. Consumidores e cidadãos: conflitos multiculturais da globalização. Rio de Janeiro, Editora UFRJ, 1995.

COCHRANE, Kira. All the Rebel Women: The Rise of the Fourth Wave of Feminism. Londres, Guardian Books, 2013. 
CONNELL; Robert. Masculinities. California, University of California Press, 2005.

DARDOT, Pierre; LAVAL, Christian. A nova razão do mundo: ensaio sobre a sociedade neoliberal. São Paulo, Boitempo, 2016.

DOUGLAS, Mary; ISHERWOOD, Byron. O mundo dos bens: para uma antropologia do consumo. Rio de Janeiro, Editora UFRJ, 2006.

FURINI, Liana Gross. MALINI, Fábio; ANTOUN, Henrique. A internet e a rua: ciberativismo e mobilização nas redes sociais. Contemporânea (14), Salvador, 2016, pp.125-127.

FISCHER, Rose Maria Bueno. O dispositivo pedagógico da mídia: modos de educar na (e pela) TV. Educação \& Pesquisa (28), São Paulo, 2002, pp.151-162.

FRASER, Nancy. Como o feminismo se tornou subalterno ao capitalismo - e como reivindicá-lo. 2016. [https://www.geledes.org.br/como-o-feminismo-se-tornou-subalterno-ao-capitalismo-e-como-reivindica-lo/acesso: 08 fev. 2017].

FRASER, Nancy. O feminismo, o capitalismo e a astúcia da história. Mediações, Revista de Ciências Sociais (14), Londrina-PR, 2009, pp.11-33.

FOUCAULT, Michel. Microfísica do poder. 7.ed. Rio de Janeiro, Graal, 1979 [1978].

GILL, Rosalind. Postfeminist media culture:Elements of sensibility. EuropeanJournal of Cultural Studies (9), Londres, 2007, pp.147-166.

GOLDMAN, Robert. Reading Ads Socially. Londres, Routledge, 1992.

GUTIÉRREZ, Lorraine Margot; LEWIS, Edith Anne. Empowering women of color. Nova Iorque, Columbia University Press, 1999.

HARVEY, David. O enigma do capital: e as crises do capitalismo. São Paulo, Boitempo, 2011.

HILL COLLINS, Patrícia. Black Feminist Thought: knowledge, consciousness, and the politics of empowerment. Nova Iorque, Routledge, 2000 [1990].

ILLOUZ, Eva. O amor nos tempos do capitalismo. Rio de Janeiro, Editora Zahar, 2011.

LATOUR, Bruno. Jamais fomos modernos: ensaio de antropologia simétrica. Rio de Janeiro, Ed. 34, 1994.

LIMA, Ana Maria Abreu de. O Empowerment feminino na publicidade: um estudo exploratório sobre as percepções e atitudes dos consumidores. Dissertação (Mestrado em Ciências da Comunicação), Universidade do Minho, 2016.

LIPOVETSKY, Gilles; SERROY, Jean. A estetização do mundo: viver na era do capitalismo artista. São Paulo, Companhia das Letras, 2015.

LOURO, Guacira Lopes. Gênero e sexualidade: pedagogias contemporâneas. Pro-Posições (19), Campinas, SP, 2008, pp.17-23 [http://www.scielo.br/pdf/pp/v19n2/a03v19n2.pdf. - acesso em: 10 de mar. de 2017].

MACEDO, Ana Gabriela. Pós-feminismo. Revista Estudos Feministas (14),Florianópolis-SC, 2006, pp.813817.

MCCLINTOCK, Anne. Couro Imperial: Raça, Gênero e Sexualidade no Embate Colonial. Campinas-SP, Editora da Unicamp, 2010.

MCROBBIE, Angela. Post-feminism and popular culture. Feminist Media Studies, (3), Londres, 2004, pp.255264.

MCROBBIE, Angela. The Aftermath of Feminism: Gender, Culture and Social Change. Londres, Sage, 2009.

MOHANTY, Chandra Talpade. Under Western Eyes: Feminist Scholarship and Colonial Discourses. Boundary (3), Durham- CN, Durham University Press,1984, pp.333-358.

MORENO, Raquel. A beleza impossível: mulher, mídia e consumo. São Paulo, Editora Ágora, 2008.

MARX, Karl. O Capital. São Paulo, Centauro Editora, 2005.

MATOS, Marlise. Movimento e Teoria Feminista: É possível reconstruir a Teoria Feminista a partir do Sul Global? Revista de Sociologia e Política (36), Curitiba, PR, 2010, pp.67-92. 
MUKJERJEE, Roopoli; BANET-WEISER, Sarah. Commodity Activism: Cultural resistance in neoliberal times. Nova Iorque, New York University Press, 2012.

OKIN, Susan. Gênero, o público e o privado. Revista Estudos Feministas (16), Florianópolis-SC, 2008, pp.305-332.

PISCITELLI, Adriana. Interseccionalidade, categorias de articulação e experiências de migrantes brasileiras. Sociedade e Cultura (2), Goiânia-GO, 2008, pp.263-274

SCHUMPETER, Joseph. Capitalismo, socialismo e democracia. Rio de Janeiro, Zahar Editores S.A., 1984

SCOTT, Linda. Marketfeminism: the case for a paradigmshift. In: CATTERALL, Mirian; MACLARAN, Pauline; STEVENS, Lorna (org.). Marketing and Feminism: Current Issues and Research. Nova Iorque, Routledge, 2000, pp.16-38.

SHOWDEN, Carisa. What's Political about the New Feminisms? Frontiers: A Journal of Women Studies (39), Colorado, 2009, pp.166-198.

SKEY, Samantha. \#Femvertising: A new kind of relationship between influencers and brands. iBlog Magazine, 2015 , [http://cdn.sheknows.com/corporate.sheknows.com/production/nodes/attachments/24521/iBlog MagazineSheKnows-FemvertisingFeature.pdf? 1429105587 - acesso em: 05 jan. 2017].

SLATER, Don. Cultura do consumo e modernidade. São Paulo, Nobel, 2002.

TRINDADE, Eneus; PEREZ, Clotilde. O lugar do sujeito consumidor entre mediações e midiatização do consumo: uma perspectiva latino-americana. Anais do $25^{\circ}$ Encontro Anual da Compós, Goiânia-GO, 2016, pp.1-17 [http://www3.eca.usp.br/sites/default/files/form/biblioteca/acervo/producaoacademica/002773893.pdf - acesso em: 17 de out 2019].

WOLF, Naomi. O mito da beleza: como as imagens de beleza são usadas contra as mulheres. Rio de Janeiro, Rocco, 2009. 